\title{
PERCEIVED QUALITY DIMENSIONS IN DISTANCE EDUCATION: Excerpts from Student Experiences
}

\author{
Asst. Prof. Upasna THAPLIYAL \\ University School of Open Learning \\ Panjab University, Chandigarh, INDIA
}

ABSTRACT

Distance education by its nature differs from the regular mode of higher education. A viable option for providing access to higher education for students who cannot attend traditional, on-campus courses, distance education, often gets a tag of being sedentary. This puts into question the qualitative aspect of the distance education courses. Distance education therefore often confronts a perception that its programmes, learning materials, and student support are not of a high standard (Badat, 2005).

Evaluation of the effectiveness of distance learning should focus mainly on students' academic performance and their feedback on their learning experiences. The present study intends to study the quality facet of distance education and its dimensions as perceived by the students enrolled in distance education courses. For conducting the study, 100 students pursuing Masters of Education (M.Ed.) from University School of Open Learning, Panjab University, were selected. Students were asked to give their feedback on areas associated with the quality like, aims and objectives of the course, teaching of the course content, curriculum transaction, learning material, student support services, evaluation procedures, infrastructural facilities and general perspective of the overall learning environment. To study the quality dimensions as perceived by the learners, content analysis was incorporated. The results reveal that the students are satisfied with the overall quality of distance education courses. The areas that emerged to be a matter of concern in the present study are student support services and infrastructural facilities available in the institutions offering distance education courses.

Keywords: Quality, quality dimensions, distance education, course experiences, student evaluation.

\section{INTRODUCTION}

Goel and Goel (2000) remarked, "Distance Education has the potential and capacity to provide general consequently, the basic characteristics of distance education are spatial separation of the teacher from the learner, an age heterogeneous learner group, easy availability and diversity in the nature of the programme offered by various universities. Education, today, faces the force of globalization, deregulation, privatization and fast socio-economic changes through continuous developments in these areas challenge distance education system to be perfect, practical and operational." On the basis of 248 studies compiled by Russell (2000), he concluded that there is no significant difference between distance learning and traditional classroom learning. In other words, distance learning (can be) considered as effective as face-to-face learning. 
Inman, Kerwin, and Mayes, 1999 found that the students in distance education courses were highly satisfied with the instructors and the distance courses taught. Drennan, Kennedy and Pisarski (2005) found in a study conducted on 250 students pursuing distance education courses and concluded that student satisfaction is influenced by positive Perceptions toward technology and an autonomous learning mode.

\section{QUALITATIVE DIMENSION OF DISTANCE EDUCATION}

Indian complex socio-economic system as much as access impacts quality and access, so does quality impact access (Premji, 2003). The concept of quality as per the UGC recommendations (2003) "the alternative dynamics for teacher preparation and the sustaining quality in teacher input, like: Curriculum design and development; Curricular practices vis-à-vis emerging principles of pedagogy; Evaluation of learners performance and progress vis-à-vis curriculum evaluation; and, Quality management practices become crucial.

The quality of these components may also differ from institution to institution. Therefore, sharing of the experiences among institutions on quality issues may generate ideas for evolving norms and strategies for their quality assurance of management processes, curricular inputs and practices and the evaluation system as well."

Education quality is a complicated phenomenon which is influenced by many factors (Targamadze et al., 2010). While designing, developing, and delivering distance education courses, students' needs and perceptions should be central. A course failing to meet student expectations and needs eventually leads to lower levels of student involvement (Hall, 2001). McAnanay (1975) developed five broad criteria of quality education which provides us useful insight for improvement of the ODL system. These are: Efforts, Performance, Adequacy, Efficiency and Process. Efforts refer to the initiatives taken by the institution. These initiatives are associated with growth in terms of courses offered, learners enrolled, pass out rates, learner support services provided, evaluation mechanism adopted etc. The growth in these criterions would reflect on the performance of the institution.

The quality of distance education varies, like any other form of education. Its quality can be the result of a variety of factors; some are intrinsic while others are extrinsic to distance education organizations. Some of these (intrinsic and extrinsic) factors include the levels of skills and expertise of staff, the amount of resources available, weak or strong leadership, efficiency of its administration systems, or the communications infrastructure in a country (Robinson, 1995).

\section{NEED FOR QUALITATIVE ASSESSMENT}

As distance education becomes more accepted as a legitimate form of education and as colleges and universities attempt to meet the growing demand for courses and programmes for distance learners, one major concern is the aspect of quality.According to Dharanajan (2002), the primary issue for distance learning institutions, like for conventional ones, is quality and the assurance that students are being provided with the best possible education or training with the highest possible standards. 
Quality in open and distance learning (ODL) is often judged in terms of the learning materials whatever the medium (Robinson, 1995). However, any distance education programme is more than just the learning materials but it is about the totality of experience of the learner. Mowen and Parks (1997) argue that there are serious questions about the integrity of distance education programmes and how students perceive their overall quality.

Robinson (1995) argues that the success of distance education programme depends on how well the course production, delivery and student support sub-systems function. For example, excellent learning materials may prove a little help to the learners if not delivered on time.

\section{RATIONALE OF THE STUDY}

This research study is an attempt to see whether the distance education programmes qualify the quality criteria as perceived by the students. How well the courses fare with regard to aspirations of the learners? The distance education institutions are in the pursuit of implementing a quality culture. This study endeavors to identify the elements that reflect quality. Did the learning environment offered to them meet their expectations? Economics of distance education considers learners to be the consumers in the educational process. So, eventually the target group of students is one of the primary stake holders whose views and opinions need consideration in evaluating the effectiveness of quality initiatives in any distance education programme and hence, this study has the focus on quality dimensions as perceived by students.

\section{METHODOLOGY}

To study the quality facet of distance education courses and its dimensions as perceived by the students enrolled in distance education courses, 100 students pursuing Masters of Education (M.Ed.) from University School of Open Learning, Panjab University, were selected. Considering the regulations of National council for Teacher Education (N.C.T.E.), the teacher education course at masters level are meant for in-service teachers with a minimum of 2 years teaching experience in government or government recognized schools.

The students were asked to give their feedback on areas like, aims and objectives of the course, teaching of the course content, curriculum, learning material, student support services, evaluation procedures, infrastructural facilities and general perspective of the overall learning environment at the end of their personal contact programme. To study the quality dimensions as perceived by the learners, content analysis of the written account from the students was incorporated to see the quality dimensions of the distance education course they had pursued.

\section{STUDENTS' PERCEPTION ON QUALITY DIMENSIONS}

\section{Course Objectives}

The course objectives directly reflect the overall picture of the course. It is like a blueprint for course development. The course objectives should cater to student's needs and learners should be able to anticipate what kind of work is expected from them and how should they progress towards achieving the targets they set for themselves. 
The written accounts of student experiences revealed that most of the students were satisfied as far as aims and objectives of the course are concerned but, at the same time they were anxious about how many objectives would they actually be able to achieve once they are through the course.

\section{Quality of Teaching}

Students want to be able to supplement, and even replace, conventional learning experiences with distance education experiences. Learners say this is because many other considerations besides personal preferences motivate them, especially considerations about where and when they learn (Picciano \& Seaman, 2007). These opposing preferences pose a dilemma for the aspirants of higher education enrolling in distance education.

Almost all the students were of view that the quality of teaching during the personal contact programme was excellent and they were able to understand the concepts. The students believed that the faculty was committed towards their job. The whole teaching process according to the learners was well organized, directed, and covered almost all the content. Also, the students considered the contact programme very beneficial with regard to the semester exams.

One of the student comments in this regard, "Teachers here are committed towards their job. Faculty works hard for the class which reflects from their teaching. Teachers are well informed and take their classes very seriously."

\section{Curriculum Transaction Strategies}

In this study, it surfaced that students are conscious about their limitation on face to face interaction among each other and with teachers. This is the reason why faculty members also emphasize on interactive mode of curriculum transaction. In the situations, where the students do not meet expectations, teachers make an effort to improve the communication process.

The content is taken up unit-wise to avoid any confusion among the learners. The faculty takes up the task of covering up the topics as per the scheduled time-table prepared for the personal contact programme hours.

Following was the feedback of one of the students: "The class-room sessions are interactive in nature and the students are encouraged to question whenever they encounter any kind of a confusion or doubt. The students are encouraged to voice their opinion and participate in discussions."

Another student remarked: "Teachers try to take up the topics in a sequential and logical manner and this helps the students ascertain that how much of the prescribed syllabus has been covered in the classes which further helps in taking the house tests and semester examinations."

\section{Learning Material}

The very nature of distance education discourse makes quality of the study materials as the touchstone of success and failure of any course being run in the institution. Learning material keeps the students in touch with the subject content. 
Students strongly believe that they could learn well and independently as long as they are facilitated by well-structured course materials, usually provided to the students in self-learning mode, which guided them step by step on how to study the content of the course. The faculty of distance education improvises on the learning materials as per the changes in the prescribed curriculum as well as according to the learners' feedback on the material during the contact programmes. The content for each subject is divided into "blocks" and each block consists of the topics prescribed in the syllabus of the course.

Students were largely satisfied with the learning material provided. As per the feedback received from a student, it remarked: "The content in the notes is comprehensive and extensive. It is easy to understand the concepts from the study material. I found the material very helpful."

\section{Student Support}

Krishnan (2012) defines student Support Services (SSS) as cluster of facilities and activities that are provided to make the learning process easier and more interesting for the learners. In distance education, they serve as the interface between the institution and the learner.

At the time of admission, students are given prior intimation of the personal contact programmes schedule and learning material for the first semester is also given. This enables students to make arrangements for attending the mandatory contact programme. However, majority of the students emphasized that assignment for the subjects should be given to them before the personal contact programme so that they get enough time to prepare them as the assignment work is to be submitted during the contact programmes only.

The students were of the opinion that the contact programme not only breaks their isolation from studies but also provides them opportunity to interact with the fellow students and share experiences with them. Social interaction in this manner, acts as support for the learners as they seek help from the fellow students when they encounter any problematic situation. Even though the efforts are directed towards making the learner comfortable, but some aspects do irk learners when they come for the contact programmes. In particular, the students were not satisfied with the facilities available in the library. Also, the laboratory equipments were not sufficient to do the practical work and they face problems in tasks associated with the practical components.

\section{Infrastructural Facilities}

Infrastructural facilities included building, library facilities, learning resources, laboratories, hostel and accommodation facilities etc. Resources should be dedicated to improving the traditional educational infrastructure of buildings, classrooms, laboratories, and also, it should be examined whether these facilities are accessed by the learners. Students should be made aware of these facilities available to them. From the present study it emerged that the existence of and access to ICTs did not ensure their effective utilization as most of the students though being computer literate could not trust the information available on the web as because of the information overflow. One of the students reported in this regard: "I find the learning material supplemented with the class notes sufficient for making notes and preparation for semester end exams." 


\section{Assessment and Evaluation}

Assessment and evaluation is a critical aspect associated with the quality dimension of any educational programme. This aspect affects the student learning outcome in the form of achievement motivation. Fair and square evaluation ensures that due recognition to the student efforts has been given by the teachers. Students also, like to receive good grades.

Most of them work hard to deliver their best of capabilities to an assigned academic task. In case of M.Ed. programme internal assessment criteria is based on the following components:

$>$ Classroom interaction: based on how consistent the sudden is attending the classes and his/her behavior in the class, whether the student is attentive, whether he/she interacts with the teacher, asks questions or gives inputs in the classroom discussion and participates in activities.

$>$ Assignment work: It is the responsibility of the student to complete assignment work in a timely manner and submit them in the prescribed time limit. The assignments are graded for originality, relevance and appropriate content.

$>$ Snap/house tests: Evaluation is done on the basis of written examination during the personal contact programmes. These tests are taken for the subjects' students study in a particular semester.

On combining these components student's internal assessment is finalized. Thus, the student evaluations are made very objectively and they can easily analyze their performance on the basis of their internal assessment.

External examinations (theory as well as practical part) take place at the end of each semester. Students were satisfied by the assessment criteria and hardly any confusion or doubt emerged in relation to evaluation as they considered the evaluation system very transparent in nature.

\section{CONCLUSION}

The present research sought to illuminate students' perceptions of the quality of the distance education programme on the basis of their learning experiences. As per feedback received by students, the following conclusions can be drawn which are directly related to effectiveness of distance education course:

$>$ Distance education courses should be carefully designed and developed before teaching process actually begins.

$>$ Effective instructional strategies for learners should be designed by the teachers keeping in view the time constraint during the contact hour programmes.

$>$ Adequate support systems must be in place to provide the distant learner with access to learning resources such as text books, learning material etc.

$>$ Interaction between the teachers and students and among students (peers) must be encouraged and practiced.

$>$ Assessment should be designed to relate to specific learning outcomes of the learning experiences. 
Asst. Prof. Upasna THAPLIYAL is M.Sc. Mathematics, M.Ed., UGC-NET qualified and presently working as an Assistant Professor in Education in the Department of Education, University School of Open Learning, Panjab University, Chandigarh for the last five years. She has been enrolled for the research work in the faculty of Education from the Panjab University and has been actively participating in the activities like seminars, workshops and conferences related to the field of educational research.

Asst. Prof. Upasna THAPLIYAL

University School of Open Learning

Panjab University, Chandigarh, INDIA

Email: upasna13april@gmail.com

\section{REFERENCES}

Badat, S. (2005). South Africa: Distance higher education policies for access, social equity, quality, and social and economic responsiveness in a context of the diversity of provision. Distance Education, 26 (2), 183-204.

Dharanajan, G. (2002). Open and Distance Learning in Developing Economies. UNESCO Conference of Ministers of Education of African Member States, December 6.

Drennan, J., Kennedy, J. \& Pisarksi, A. (2005). Factors affecting student attitudes toward $s$ flexible online learning in management education.

The Journal of Educational Research, 98 (6), 331-340.

Goel, A. \& Goel, L. S. (2000). Distance Education in 21st Century. Deep \& Deep publishers, Rajouri Garden, India: New Delhi.

Hall, J. C. (2001). Retention and wastage in FE and HE. The Scottish Council for Research in Education. http://www.ulster.ac.uk/star/resources/retention\%20and\%20wasta ge_hall.pdf

Inman, E., Kerwin, M. \& L. Mayes. (1999). Instructor and student attitudes toward distance learning. Community College Journal of Research \& Practice, 23 (6), 581592.

Krishnan, C. (2012). Student Support Services in Distance Higher Education in India: A Critical Appraisal. International Journal of Research in Economics \& Social Sciences, 2(2), 459-472.

McAnanay, E. G. (1975). Radio schools in non-formal education: an evaluation perspective. In La Belle, T. J. (Ed.) Educational Alternatives in Latin America: Social Change and Social Stratification. UCLA Latin, Los Angeles: America Centre Publications.

Mowen, A. J. \& Sara, C. P. (1997). Competitive Marketing of Distance Education: A Model for Placing Quality Within a Strategic Planning Context. The American Journal of Distance Education, 11(3), 27-39. 
Premji, A. (2003). Wipro Applying Thought in Schools. Jawaharlal Nehru Memorial

Lecture. Retrieved from http://www.wiproapplyingthoughtsschools.com/?q=node/33

Rai, N. A (2000). Distance Education Open Learning VS Virtual University Concepts, E35/103, Jawahar Park Laxmi Nagar, New Delhi: India.

Russell, T. (1999). No significant difference phenomenon. Raleigh: North Carolina State University.

Targamadze, A., Petrauskiene, R. \& Rubliauskas, D. (2010). Influence of technologies on quality of distance learning. Electronics and Electrical Engineering Informatics Engineering Sciences, 6 (2), 131-134. 